УДК: 7.041 .5

ББК: 85.143

A43

DOI: $10.18688 /$ aa200-2-21

P. Chebakova, E. Skvortcova

\title{
Sense and Sensibility: The Theme of Friendship in the Russian Portrait Painting of the Enlightenment Era
}

The importance of friendship for the culture of Enlightenment was arguably best articulated by the organizers of an exhibition celebrating Johann Wilhelm Ludwig Gleim and his literary circle at Gleimhaus, Halberstadt, entitled "Das Jahrhundert der Freundschaft" ("The Century of Friendship") [41]. The new ways of thinking about and experiencing friendship brought by the $18^{\text {th }}$ century were traced by D. Garrioh who described them as a crucial shift "from Christian friendship to secular sentimentality" [16]. M. W. Reddy examining the case of France made an emphasis on friendship being one of new forms of sociability offering in policed society "emotional refuge from the increasingly elaborate honor code" alongside with salons, Masonic lodges, lively private networks of correspondence and affectionate marriage [42, pp. 145-146, 149]. As a result, the $18^{\text {th }}$ century produced a peculiar style of friendly conversation cherishing easiness and intimacy, flexibility of mind and subtle moods [19, p. 331].

On the material of $18^{\text {th }}$-century Russian literature, memoirs and correspondence, the theme of friendship was examined by G. Gukovskii, Iu. Lotman, N. Kochetkova, N. Aleksandrova, L. Pastushenko, E. Alikova $[18 ; 29 ; 23 ; 1 ; 36 ; 4]$. Heroic friendship as a subject of Russian academic mythological painting was analyzed by N. Kovalenskaia [28, pp. 140-141, 201]. Emanations of friendship in portrait of sentimentalism were addressed by G. Zhidkov [56, p. 116] and sociologist I. Kon [26, p. 79]. G. Vdovin's profound analysis of formation of notions of individuality and personality in $18^{\text {th }}$-century Russian culture and correspondent evolution of psychological aspects of portrait painting laid the foundation for further examination of forms of personal interrelationship and their reflection in art [52]. On the whole, in Russian historiography friendship as a cultural phenomenon and sociability practice attracted less attention than in Europe and is better explored in literary studies than in the history of arts. The latter is still to offer much for the understanding of the specifics of notion of friendship in Russian Enlightenment which is indeed significant as friendship lies at the heart of the culture of this epoch.

Recent foreign research of Enlightened friendship based primarily on the material of visual arts usually interprets it as a social commerce and stresses the questions of spaces of sociability, their reflection in art, the effect of friendship on artistic production, i.e. creating, collecting and exchanging portraits etc. $[15 ; 31]$. This paper concentrates on a narrower aspect, namely representation of bonds of friendship in $18^{\text {th }}$-century Russian art, particularly in double oil portrait. This subgenre of portraiture appears to be particularly suitable for the task, firstly, due to the notion of the true friend's being a person's "double", his "alter ego", which goes back 
to Antiquity [15, p. 87] and, secondly, due to the fact that group portraits were less widespread in Russian art of the period and limited to family portraits. The type of a multi-figured "conversation piece", including alongside with familial portraits-scenes "conversations with a well chosen friend", so influential in British art [44, pp. 23, 251-285; 24], did not take root in Russia. The concept of friendship as a freely-chosen relation outside family based exclusively on personal inclination can appear rather problematic when it comes to double portraits in Russian art since most of the models depicted are relatives. However, in a double portrait a "reduced type" of a group family portrait demonstrating selective approach to the family members - the very choice of models needs explanation which can be found at least in some cases in the ties of friendship.

The paper covers the entire $18^{\text {th }}$ century with an emphasis on its second half. Such a timespan enables to trace through the prism of visual art the evolution of the idea of secular friendship which relevance dramatically increased since 1750 s from its beginnings. The context of European Enlightenment used for definition of a certain type of friendship typical for the period demands correspondence with the same age in Russian culture. The ground for Russian Enlightenment was prepared by reforms of Peter the Great who, as W. Gareth Jones formulated it, "reshaped Muscovy, with its Orthodox religious culture into a modern, secular European state" [20]. J. H. Billington argues that it was already by the 1750s that "many-sided effects of Peter's opening to the West had begun to reach a fruitition that can properly be called a Russian Enlightenment" [9]. Still, indubitably, Enlightenment in Russia reached its pinnacle in the reign of Catherine II who was adherent to its ideas. And it was in the same time that representation of friendship in portraiture did acquired importance.

Western concepts of friendship were deeply influenced by classical ideas. The Greek term philia, normally translated as "friendship", encompassed a wide range of relationships such as family members, loved ones, acquaintances, close companions, "guest friendship", collaborators in a project. Classification of friendship relations was provided by Aristotle who paid particular attention to advantage-friendship, pleasure-friendship and virtue-friendship. The latter was considered the rarest and the most valuable [11, p. X, 25; 8, pp. 1-64]. Ancient ideals were summarized by Cicero in his "De Amicitia" in which he defined friendship as the highest and rare form of social bond which can exist exclusively between virtuous men and is formed upon unanimity of tastes, pursuits, sentiment and interests, so that in a friend man beholds a copy of himself [27, pp. 9-12]. After the Middle Ages when concepts of friendship presupposed shared belief in and love of Christ classical ideals were revived in the Renaissance and resonated well into the $18^{\text {th }}$ and $19^{\text {th }}$ centuries $[11, \mathrm{p}$. XI]. It was in courtly culture of Italian Renaissance with its cult of friendship that a special type of "friendship portrait" emerged [ 49 , p. 284]. Its most usual form were paired likenesses characterized by mood of privacy and intimacy (Pontormo, Portrait of Two Men. C. 1524. Venice, Fondazione Giorgio Cini; Sebastiano del Piombo, Portrait of Verdelotti and Ubretto. Destroyed, formerly Berlin, Gemaildegalerie, Staatliche Museen Preussischer Kulturbesitz) [35, p. 270; 49, p. 284].

In $18^{\text {th }}$-century Russia selective adoption of European traditions of iconography was predestined by national cultural traditions as well as existence, importance and relevance or absence of certain notions. The first half of the $18^{\text {th }}$ century offers only one portrait which can be linked with European tradition of friendship portrait. Louis Caravaque's "Portrait of Anna 
Petrovna and Elizaveta Petrovna" (1717, State Russian Museum), as noted by L. Vasser, demonstrates formal accordance with criteria of Van Dyck's female friendship portrait (threequarter presentation of models sitting) [51, p. 236]. The graceful ease of animated interplay between the figures implies friendly relationship of the young girls, certain intimacy is suggested by dresses leaving breasts partly open.

Friendship as interpersonal relationship entails the existence of two individuals. Emancipation of "ego" from the Medieval collective consciousness, which arose in Europe in the time of Renaissance, in Russia started in the mid- $17^{\text {th }}$ century and occupied the whole $18^{\text {th }}$ century undergoing in terms of Vdovin three stages: "персона" (persona) - "индивидуальность" (individuality) - “личность" (person) [52]. Underdeveloped idea of personality impeded emergence of friendship portraits in Russian art of the end of the $17^{\text {th }}$ - the first half of the $18^{\text {th }}$ century as an extensive phenomenon.

Apart from double oil portraits exceptionally rare in this period (especially if we exclude portraits of spouses), there were several spheres in which double representation existed involving spectrum of meanings cognate to friendship. One of them was representation of corule of Ivan V and Peter I. In F. Iollain's engraving (1685) their parallel depictions and the gesture of hand-holding visualize their equal power and collaboration as co-rulers. Nicolas de Larmessin's engraving (1685) is less formal due to half-length format and combination of enface and profile portraits, but still has the function of representation of power rather than relationship between the two persons (about them: [14]).

Parallel depiction also became conventional for emblematic and allegorical conveyance of peace treaty putting end to war and marking the beginning of conflict-free, friendly relationship. Some of them feature symbolic representation of the two countries, as in the medal celebrating the Treaty of Nystadt with Noah's arch and dove with an olive branch in the center and the cities of Saint-Petersburg and Stockholm on both sides united by the rainbow (Russia, $18^{\text {th }}$ century, reproduced in [17, pp. 48-49]). Others, more important in this context, presented personifications, as in the following examples: 1) firework celebrating the Treaty of Nystadt arranged in Saint-Petersburg on $22^{\text {nd }}$ October 1721 with two crowned knights closing the Temple of Janus and shaking hands ${ }^{1}$; 2) Carlo Bartolomeo Rastrelli and Andrei Nartov's medallion celebrating the same treaty depicting two crowned men in armory shaking hands (1720s, The State Hermitage Museum, St. Petersburg, ill. 1) [51, p. 427]; 3) a triumphal arch in Moscow commemorating the treaty of Nystadt featuring a depiction of two tsarinas embracing each other, one personifying Russia and the other - Sweden, with an inscription "Truth and Peace Kissing" ("Две иарицы объемлются: одна в палюдаменте красном, Россию знаменующая, а другая в тазоревом, знаменующая Швецию. Надписание: Правда и Мир облобызастася») [50, p. 228]. Preceding the full-fledged emergence of friendship portrait in Russian art, such images established double depiction as a transmitter of ideas of peace and concord akin in meaning to friendship. In European art iconography of peaceful relationship of states existed not only in an allegorical form, but also in form of portraits of the rulers, personifying their states and

Bergholtz F.W., von. Dnevnik kamer-iunkera Berkhgol'tsa, vedennyi im v Rossii v tsarstvovanie Petra Velikogo, s 1721 po 1725 god. Perevel s nemetskogo I. Ammon (The Kammerjunker Bernholtz's Diary which He Was Writing in Russia during the Reign of Peter the Great, from 1721 to 1725. Translated from German by I. Ammon). Part 1: 1721. Moscow, Katkov Publ., 1857, p. 198 (in Russian). 
demonstrating the same principles of parallel depiction (for instance, Johann Flink (attributed to), "Double Portrait of Friedrich Wilhelm von Brandenburg and Johann Georg II of Saxony", c. 1660, Staatliche Kunstsammlungen, Dresden; Louis de Silvestre, "Portrait (Allianzporträt) of August II of Poland and Friedrich Wilhelm I of Prussia", before 1730, Staatliche Kunstsammlungen, Dresden). There is such a depiction of Peter I and Wilhelm III on a medal in honor of their meeting in Utrecht (1697, Jan Smeltzing, Nicolas Chevalier).

An exclusive early example of interplay of allegorical iconographic patterns and double portrait is Louis Caravaque's likeness of Anna and Elizaveta (c. 1721-1723?) from Chenar study of Marly palace in Peterhof (known after archival photograph and a copy after it) [46]. As revealed by recent research, the artist projected allegorical iconography of Pax (peace) in a form of two female figures with correspondent attributes onto a portrait of Peter's daughters presumably in relation to Russia's triumph in the Great Northern War [47]. The task of compositional assimilation of sitters in double portrait is resolved here on allegorical level. Such a decision offers an alternative to the psychological way of integration of models in a composition which on the germinal stage of development of personality's self-awareness in culture is usually replaced, as Vdovin asserts, by "единство предстояния" [52, p. 30], that is to say, the unity of the state of abstracted encounter with beholder.

Yet genuine birth of double portrait in Russian art occurred in the second half of the $18^{\text {th }}$ century. It was in same period that the importance of notion of friendship substantially increased. "Russian National Corpus" reveals that in the first half of the $18^{\text {th }}$-century frequency of mentioning of the word "friend" ("дpyz", "drug") in the sources included into it hardly exceeded 100 word-forms (out of 1 million word-forms). By the middle of the $18^{\text {th }}$ century it approached 300 word-forms, since the 1750s it grew rapidly reaching 600 and then was fluctuating, remaining generally pretty high ${ }^{2}$.

An elaborate explanation is offered by the Dictionary of the Academy of Science (1790) the first comprehensible dictionary of the Russian language. According to it, a friend is "a unanimous comrade, sincere in happiness and unhappiness, united by similarity of disposition and above all similarity of rules of honesty" (единодушный, искренній в въ щастіи и нещастіи, сотоварищъ, соединённый сходствомъ нравовъ а паче сходствомь правиль честности). Friendship is "mutual love based on sincere respect, absolute trust, similarity of disposition and the same rules of honesty" (взаимная любовь на искреннемъ почтеніи, совершенной довпренности, сходствп нравовъ и на одинакихъ правилахъ честности основанная, here and further translated from Russian by the authors) $)^{3}$. Worthy of mention is usage of a word "дружка" ("druzhka", a cognate of "drug", "friend") to describe multiple objects, most usually paired ones, which were intended to be together including portraits, which addresses us to the nature of friendship as a union of congruent persons. Summing up, the notions reflected in the Dictionary largely corresponded to European ideal of "virtuous friendship" requiring affinity of temper and views, exclusive sincerity and trust.

\footnotetext{
2 Natsional'nyi korpus russkogo iazyka (National corps of the Russian language). Available at: http:// search1.ruscorpora.ru/ngram.xml? mode $=$ main \&t $1=\% \mathrm{D} 0 \% \mathrm{~B} 4 \% \mathrm{D} 1 \% 80 \% \mathrm{D} 1 \% 83 \% \mathrm{D} 0 \% \mathrm{~B} 3 \&$ start $=1700 \&$ en $\mathrm{d}=1800$ \&smoothing $=0$ (accessed 17 January 2020).

Slovar' Akademii Rossiiskoi (Dictionary of the Russian Academy), vol. 2. St. Petersburg, Imperatorskaia Akademiia Nauk Publ., pp. 766-774 (in Russian).
} 
An important question is whether family members can be considered friends. In Europe most of treatises, unlike literary works, proclaimed parent-child relations unequal which excludes friendship, while fraternity was regarded no more than "the opportunity and the preliminary disposition to friendship" [16, p. 171]. In Russian art of the period in question there are very few portraits of friends who were not family members. The specific cult of family in the Russian culture $[24,25]$ implying friendship as a preordained facet of familial relationship, seems to be dominating. Still, portraits of father and child or mother and child with a figure of a parent normally dominating demonstrate iconographic patterns distinctively different from those grounded on the idea of equality which traditionally visualize friendship both in European and Russian art. Under specific conditions of rhetoric culture with strong traditions of emblematica, physiognomy and language of bodily movements, within which each individual unit of the face and body can be decoded as a visualization of a state of a soul [45, p. 416], postures and gestures obtain certain fixed meanings and can be interpreted as signs of particular bonds between people. Some double portraits of brothers or sisters fit into conventional iconography of friendship. The important precondition for this was the fact of the choice for the portrait of particular two brothers or two sisters from all the children of the family was based on the relation of friendship between them.

Another principal question in connection with representation of friendship is correlation of sense and sensibility. Supremacy of sense is traditionally considered one of the major ideological settings of the style of neoclassicism of the $2^{\text {nd }}$ half of the $18^{\text {th }}$ century in art (defined in Russia due to the specifics of development of art in Russia as "classicism" [53]). On contrary, the culture of sensibility, or sentimentalism, was considered a distinct movement developing as opposition to the rationalism of the period. T. Alekseeva analyzing V. Borovikovskii's portraits of the first decade of the $19^{\text {th }}$ century points to intermingling of traits of classicism and sentimentalism (1975) [3, p. 239]. Whilst Alekseeva interpreted both with regard to stylistics, much broader and more radical conclusions were reached by D. Denby on the base of analysis of European material who insists that "reason and sentiment can no longer be posited as contradictory polarities in eighteenth-century cultural formations" on the whole (1994) [13, p. 240]. In the history of the Enlightenment which has for a long time been presented chiefly "as a matter of science, rationality, social contract, and natural right" [42, p. 142] was actually "no necessary contradiction between philosophy and sentiment, reason and emotion" [8, p. 105]. As sentimentalism in visual arts is deprived of integrity of style, though it worked out some distinctive formal features [54, p. 708], and the portrait of classicism is also stylistically not holistic, in connection with representation of friendship in portrait we aim rather at revealing ideas of sense and sensibility in them than at categorizing particular portraits in stylistic terms.

In European art of the second half of the $18^{\text {th }}$ century representation of friendship as a political union in form of a portrait of the two men associated with certain states evolved into less formal portraits. Some European depictions of that kind feature Russian sitters. To this type corresponds miniature portrait from the National museum, Stockholm (1770s-1780s), identified by S. Podstanistkii as a "Portrait of Grand Duke Paul and Prince Friedrich Heinrich Ludwig of Prussia" and attributed by him to Anton König. However, as neither of the models was a ruler at the time, the portrait has rather personal air about it, though this does not totally exclude state connotations [40, p. 32]. A highly curious sample of blending state theme and pri- 
vate interrelation is Cornelius Høyer's double portrait of Gustav III of Sweden and Catherine II of Russia (Nationalmuseum, Stockholm, inv. NMB 11, ill. 23), reinventing traditions of parallel depiction as a symbol of reconciliation or union in a more personal way. The two rulers are depicted during successful negotiations in Fredrikshamn in 1783 which were held in private and were "the closest contact of Catherine and Gustav that ever took place" [34, p. 23]. Gustav III prepared a draft of "a family treaty with a sentimental introduction referring to the ties of common blood and tender friendship between the two monarchs of the North" [34, p. 22]. The small size of a picture ( $26 \mathrm{~cm}$ in diameter) presupposes intimate atmosphere which is increased by interpretation of the scene in a way of a conversation piece. The idea of friendship and loyalty is emphasized by a depiction of winged figures holding hands by the altar in sopraporte.

Conventions of parallel depiction also influenced some portraits of the Russian military and ruling elites, as, for instance, "Portrait of Count Aleksei Orlov and Sveteleishyi Kniaz Grigorii Orlov" from State Historical museum, Moscow, displayed at the exhibition "Aristocratic Portrait of the 18-19 $9^{\text {th }}$ Centuries from the State Historical Museum" (State Historical Museum, Moscow, 27.02. - 12.08.2019) with a new attribution to Carl Ludwig Johann Christineck (previously attributed to Jean-Louis de Velly [2, p. 111]). The brothers wearing each his full dress uniform with orders are depicted upon the background of a tent, their postures and gestures shown in mirror symmetry: Aleksei Orlov is pointing to the naval scene shown in the left part of the painting, while Grigorii's gesture is directing beholder's attention to the depiction of Moscow attacked by plague. Glorification of the first's naval victories and the latter's decisive actions, which put an end to rebellion in Moscow in time of plague and rescued the city, structure the composition of this profoundly rhetorical painting. Honorable service to the Empress in different spheres for the good of the Fatherland and for the glory of their noble family makes them co-workers. Such cooperation was perceived as an aspect of friendship applying to the sense, as well as to notion of duty which were apanage of Classicism [21].

The idea of collaboration, or rather alliance, on the level of fraternal state rulers, or rather supposed would-be rulers, is manifested in Richard Brompton's "Portrait of Grand Duke Alexander and Grand Duke Constantine" (1781, The State Hermitage Museum, St. Petersburg) presenting the first with a Gordian knot suggestive of his identification with Alexander the Great and the latter with labarum implying likening him to Constantine the Great. The political idea behind the portrait was Catherine's Greek project according to which the Turks should be completely expelled from Europe and Constantine was to become a ruler of the new Orthodox Greek Empire on the Balkans, whereas Alexander was to succeed to the throne of the Russian Empire [43, pp. 38-41]. The overall impression is more natural and lively, but the postures and gestures are representative by their nature, there is still no genuine interaction of the figures, necessary to capture interpersonal relationship. And although friendship is certainly one of the implied sides of the future relationship of the states, reflected in the portrait, the idea of blood ties and Alexander's (that is to say: Russia's) being the elder brother is predominant.

In Johann Baptist Lampi the Elder's portrait of the same sitters (1795, The State Hermitage Museum, St. Petersburg, ill. 26; a variant in State Museum-Reserve "Pavlovsk"), now already young men, the idea of co-work of the brothers for the sake of their grandmother's enlightened Empire (now with no direct reference to the Greek project, which was not fully forgotten, but not current anymore) is revealed by their standing before the statue of Minerva - the goddess 
embodying principles of the wise rule in whose guise Catherine had herself depicted many times. Alexander, as Erin McBurney noted, "exactly mimics the pose and hand position of his grandmother" in front of the statue of the Goddess of Justice in her 1783 portrait by Dmitrii Levitskii (1783, State Russian Museum, St. Petersburg) [30, p. 386]. Predominantly state message of Lampis portrait, is expressed, however, through a more convincingly conveyed personal relationship between the sitters than in the abovementioned samples transmitted by the gesture of hand holding and nuances of postures. Ancient roots of the ideal of virtuous friendship are stressed by the bas-relief depiction of Castor and Pollux on the pedestal of the statue of Minerva: both in Antiquity and in the $18^{\text {th }}$ century Dioscuri were considered epitome and patrons of friendship [26, p. 46].

Such a state emphasis in discourse of friendship evident in male double portraits was predetermined by the specifics of Russian Enlightenment. When Russia accepted secular European ways of thought under Peter the Great, it first came into contact with the German Enlightenment which combined the rationalism of Descartes and Leibniz and the emotionalism of Protestant pietism with its emphasis on the acceptance of authority and on person's obligation to serve the community rather than individual rights. The mainstream of European Enlightenment represented by the works of French philosophers, penetrated into Russia since the 1740s and got predominant in the time of Catherine. In that period it was no longer exploited merely as an instrument to strengthen the efficiency of the state; the welfare of society and that of its members was now an important objective [20, p. 325]. However, as V. Zhivov rightly observed, whilst in France the beginning of the Enlightenment was marked by emancipation of culture from the state, in Russia the culture of Enlightenment was still "primarily mythological performance of state power" [57, pp. 151, 156].

Certain types of friendship portrait with a more personal and more sentimental accent did not become established in Russia. This concerns a Grand tour conversation piece, which existed in European art both in form of a group portrait and a double portrait (Nathaniel Dance. Hugh, Lord Warkworth, and the Rev. Jonathan Lipycatt, the Duke of Northumberland. 1763). Such images visualized young gentleman's experience of visiting the places that it "is expected a man should see" in a company of a learned, older tutor [44, pp. 265-268], demonstrating equally sense (classical education) and sentiment (admiration of art).

Rather rare in Russia was a double portrait recording creative friendship. Double portraits of artists were not very much spread in Europe as well, but still existed. As an example, consider a "Double Self-Portrait of Jean-Baptiste de Champaigne et Nicolas de Plattemontagne" (1654, Museum Boijmans Van Beuningen, Rotterdam, ill. 24) . Its sophisticated iconography was interpreted by $\mathrm{H}$. Williams as visualization of joining of hearts and minds able to transcend bodily parting and even death and blurring of the self and the other [55, pp. 215-221]. In the late $18^{\text {th }}$ century appeared paintings rendering creative friendship in feminine guise and reimagining traditions of allegoric depictions of sisterhoods of the arts, as Marguerita Gerard's "Artist Painting a Portrait of Musician" (before 1803, The State Hermitage Museum, St. Petersburg) [31, pp. 170-185], which is not a portrait depiction, but is based both on conventions of genre painting and portraiture.

In Russian art a rare sample of visualization of creative friendship is Kornilii Novoselov's miniature depicting three young men ("Portrait of Three Pupils of the Academy of Fine Arts 
(?)", 1792, State Russian Museum, ill. 25), spirited and lively, but much more humble than the abovementioned spectacular European paintings [32, pp. 75, 362-363]. A counterpart to European portraits representing apprenticeship, implying creative atmosphere and friendship of the pupils accompanying a teacher (Adélaïde Labille-Guiard, Self-Portrait with Two Pupils, Marie Gabrielle Capet and Marie Marguerite Carreaux de Rosemond, 1785, The Metropolitan Museum of Art, New York), can be found in Aleksei Venetsianov's "Portrait of Kirill Golovachevskii with Three Pupils" (State Russian Museum, 1811) presenting Inspector of the Academy with young boys [37, p. 121]. However, the idea of creative union is replaced by the idea of tutorship, demonstrating that education was perceived to a large extent as up-bringing. An essential idea of Catherine reflecting state character of Russian Enlightenment was to establish closed educational institutions in order to create "the ideal man and perfect citizen". Alongside with Academy of Fine Arts (which was established by Elizaveta Petrovna, but was given imperial charter by Catherine) an important role in the process of modernization of society was assigned by Catherine to Vospitatel'noe Obschestvo Blagorodnykh Devits. Among Dmitrii Levitskii's series of portraits of smol'nianki [10] there are two double pictures and one of them - "Portrait of Feodosiia Rzhevskaia and Nastasia Davydova" (1771, State Russian Museum) - can loosely be linked to the ideas of friendship as admiration of younger girls for older ones (Davydova and Rzhevskaia were about eight and eleven years old judging both by physical appearance and the colors of uniforms meant for certain ages) and their aspiration (with a touch of competition) to achieve the same refinement in manners and arts. This is one of rare samples of portraits transmitting the idea of friendship as extra-familial relationship.

In Europe up to the middle of the $18^{\text {th }}$ century friendship was perceived as almost exclusively male relationship. Ethical and philosophical writings maintained that women are deprived of the intellectual and moral capacity to experience such social exchange among themselves or with men. The situation changed in the middle of the $18^{\text {th }}$ century with expansion of sentimentalism ${ }^{4}$ - the term originally coined for a literary genre and has gradually extended to describe wider cultural practices characterized by "enthusiasm for emotional expression and intimacy" [42, pp. 146, 154]. Essential doctrines of sentimentalism included notions that "superior virtue is linked to simplicity, openness, and lowly rank, because virtue is an outgrowth of natural sentiments we all share" and "that women are more likely to develop such virtue" [42, p. 158]. Such a conviction enabled the emergence of an idea of female friendship in which émotion, sentiment, and sensibilité prevailed. In Russia it was not earlier than 1760-1770s that sentimentalism found its way in literature and in the 1790s in the fine arts.

The most iconic images of sentimental friendship as union of the two hearts were created by Vladimir Borovikovskii. Of special importance is "Portrait of Lizon'ka and Dashin'ka" (1794, State Tretyakov Gallery), maids (krepostnye) of the N. L'vov [5, p. 21], gently snuggling to each other and embracing. Peasant girls are turned into refined "baryshni-krestanki". The very possibility for such a transformation arises from a sentimentalist concept of virtue as an outgrowth of inborn sentiments all people have. In "Portrait of Lizon'ka and Dashin'ka"

4 W. Reddy calls "Flowering of Sentimentalism" the period between 1700-1789, describing Earl of Shaftsbury's ideas as its impetus. Still, essential doctrines of sentimentalism were presented in Richardson's "Pamela" (1740) and in the visual art revealed in Jean-Baptist Greuze's works which he exhibited in the Salon since mid-1750s [42]. 
as well as later in "Portrait of Duchesses Kurakin sisters Elena and Alexandra" (1802, Musée du Louvre, Paris) it is subtly structured composition, carefully contrived gestures and delicate modulated color scheme that make the figures appear to merge into one dual being, In "Portrait of Duchesses Gagarin sisters" (1802, State Tretyakov Gallery, Moscow) the unity is accentuated also on the level of subject, i.e. by the motive of practicing music: one sister is singing, while the other is accompanying her on guitar. In the $18^{\text {th }}$ century pursuit of any of the arts was an attribute of an "accomplished woman" and signified femininity and cultivation so important for eligible bride. M. Medakovich called a guitar "proudly hold" by sitters in numerous $18^{\text {th }}$-century female portraits "a testament of talents and social position" [31, pp. 177, 179]. Here the traditional pursuit is reinterpreted in terms of sensibility.

A highly curious sample of adoption of specific European iconography and symbolics of friendship is portrait of cousins Countess Daria Saltykova and Baroness Nataliia Stroganova known after engraving in "Edition of Grand Duke Nikolai Mikhailovich. Russian Portraits of the $18^{\text {th }}$ and $19^{\text {th }}$ Centuries" dated loosely 1760-1770s (ill. 29) [33, pp. 36, 192-194] and fragmented miniature copy in Tretyakov gallery (the end of the 1760s - beginning of the 1770s) [38, p. 23]. One lady is sitting while the other standing behind is softly leaning on her shoulder with joined arms. In the foreground is a cage and two doves rubbing each other's beaks. In Nestor Ambodik-Maksimovich's emblem book "two doves with spread wings kissing

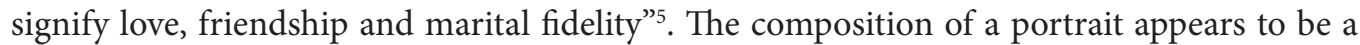
direct transcript from La bonne amitié made by Justus Chevillet (1769, etching, 45,7×32,1, ill. 28) after original by Johann Eleazar Schenau ${ }^{6}$, which was also reproduced in a porcelain statuette $[12, \text { p. } 25]^{7}$.

In Russian art of the Epoch of Enlightenment friendship portrait appears to be inseparable from family portrait. There are very few exceptions and all of them are connected with corporate friendship of young people (both male and female) inside closed educational institutions which introduced several important new phenomena into Russian social life (including, for instance, the notion of adolescence concerning ladies as R. P. Blakesley convincingly proved) [10]. Still, many portraits of brothers and sisters can be ranked among friendship portraits as they correspond to European iconography of friendship. Models of all female friendship portraits are usually sisters and are always unmarried young ladies: family life, presupposing responsibilities of caring wife and mother, was understood as incompatible with friendship outside the nuclear family. The notion of sensibility, revealed in friendship as

Ambodik-Maksimovich N. M. Emvlemy i simvoly izbrannye, na rossiiskii, latinskii, frantsuzskii, nemetskii i aglitskii iazyki perelozhennye, prezhde v Amsterdame, a nyne vo grade sv. Petra napechatannye, umnozhennye $i$ ispravlennye Nestorom Maksimovichem-Ambodikom (Chosen Emblems and Symbols, Translated into Russian, Latin, French, German and English, Printed in Amsterdam and Now in St. Petersburg, Supplemented and Corrected by Nestor Ambodik-Maksimovich). St. Petersburg, Imperatorskaia tipografiia Publ., 1788, p. LXVIII, no. 77 (in Russian).

6 La bonne Amitié, ou le mistère éclairci [Gute Freundschaft oder die wunderbare Aufklärung]. Museum-digital. Deutsches Damast- und Frottiermuseum. Available at: https://nat.museum-digital.de/index. php?t=objekt\&oges=638140 (Accessed 2 March 2020).

"The Young Bride", Meissen, after Michel Acier model, ca. 1774-1775. Victoria and Albert Museum. Search the Collections. Available at: http://collections.vam.ac.uk/item/O333836/the-young-bride-groupacier-michel-victor/ (Accessed 15 April 2020). 
union of hearts, is almost exclusively connected to such portraits depicting young ladies, while male friendship is understood in terms of sense either as a political union or collaboration. Notably, the gestures of male friendship in Russian portrait are exceptionally shaking hands and handholding whereas female or children friendship can be reflected through different gestures of embracing and snuggling. Tellingly, in Europe, on contrary, the gesture of leaning on shoulder with joined arms (as in portrait of Countess Daria Saltykova and Baroness Nataliia Stroganova) was used both in female and male portrait (Benjamin West. "Portrait of Raphael West and Benjamin West, Sons of the Artist, c. 1796, The Nelson-Atkins Museum of Arts, Kansas City, ill. 27) demonstrating sensible notes entering the latter. Vocabulary of friendship gestures established in the $18^{\text {th }}$ century both in Europe and in Russia will be preserved and not greatly enriched in the $19^{\text {th }}$ century. However, since the Epoch of Romanticism the old ideas of virtuous friendship described in the Epoch of Enlightenment in terms of sense and sensibility will be transformed into understanding of friendship as a deep innermost mystical bond of the two people which will fill the old gestures with new content expressed on the level of stylistic and subtle new accents in iconography, rather than completely new iconographic patterns.

\section{References}

1. Aleksandrova N.V. Love and Friendship in the Russian Noble Culture of the Turn of the $18^{\text {th }}-$ $19^{\text {th }}$ Centuries (on Memoir Sources). Magistra Vitae (Magistra Vitae: Online-Journal of Historical Sciences and Archeology), 1999, no. 2 (10), pp. 33-42 (in Russian).

2. Alekseev S. (ed.). Ekaterina Velikaia v strane i mire: po materialam vystavki (Catherine the Great in the Country and the World: On Materials of the Exhibition). St. Petersburg, Palace Editions Publ., 2017. 179 p. (in Russian).

3. Alekseeva T. V. Vladimir Lukich Borovikovskii i russkaia kul'tura na rubezhe 18-19 vekov (Vladimir Borovikovskii and Russian Culture at the Turn of the 18-19 th Centuries). Moscow, Iskusstvo Publ., 1975. 421 p. (in Russian).

4. Alikova E. A. Dialogue of Human and Nature in Idylls of Women Poets of the 1770-1820s. Vestnik Brianskogo gosudarstvennogo universiteta (Bulletin of the Bryansk State University), 2012, no. 10, pp. 95100 (in Russian).

5. Arkhangel'skaia A. I. Borovikovskii. Moscow, [s.n.], 1946. 61 p. (in Russian).

6. Baillio J.; Lang P.; Baetjer K. Elisabeth Louise Vigée Le Brun. New York; New Haven, Yale University Press Publ., 2016. 278 p.

7. Baltzly D.; Eliopoulos N. The Classical Ideals of Friendship. Caine B. (ed.). Friendship: A History. Oxon; New York, Routledge Publ., 2014, pp. 1-64.

8. Barker E. Putting the Viewer in the Frame: Greuze as Sentimentalist. Studies in the History of Art, 2007, vol. 72, Symposium Papers XLIX: French Genre Painting in the Eighteenth Century, pp. 104-127.

9. Billington J. H. The Icon and Axe: An Interpretative History of Russian Culture. London, Weidenfeld and Nicolson; New York, Alfred. A. Knopf Publ., 1968.

10. Blakesley R. P. Ladies-in-Waiting: Picturing Adolescence in Dmitry Levitsky's Smolny Portraits. 177276. Art History, 2017, no. 1 (37), pp. 10-37.

11. Caine B. (ed.). Friendship: A History. Oxon; New York, Routledge Publ., 2014. 414 p.

12. Cherezova L. Meisenskii farfor $v$ sobranii Tul'skogo khudozhestvennogo muzeia (Meissen Porcelain in the Collection of Tula Museum of Fine Arts). Tula, Lev Tolstoi Publ., 1994. 32 p. (in Russian).

13. Denby D. J. Sentimental Narrative and the Social Order in France, 1760-1820. Cambridge; New York, Cambridge University Press Publ., 1994. 298 p.

14. Dutov A. A. Works of Art from Ia. F. Dolgorukov's Embassy to France in 1687. Transactions of the State Hermitage Museum, vol. 70: Personalities from Peter the Great's Time - 2013, pp. 153-158 (in Russian).

15. Fripp J. L. Portraits of Artists and the Social Commerce of Friendship in Eighteenth-Century France. Ph. D. Thesis. 
Ann Arbor, The University of Michigan, 2012. 353 p. (unpublished). Available at: https://deepblue.lib.umich. edu/bitstream/handle/2027.42/94079/jfripp_1.pdf?sequence=1\&isAllowed=y (accessed 25 February 2020).

16. Garrioch D. From Christian Friendship to Secular Sentimentality: Enlightenment Re-evaluations. Caine B. (ed.). Friendship: A History. Oxon, New York, Routledge Publ., 2014, pp. 165-214.

17. Gavrilova L. M. Pol'za. Chest'. Slava. Nagrady Rossii (Benefit. Honour. Glory: Russian Awards). Moscow, Kudozhnik i Kniga Publ., 2004. 299 p. (in Russian).

18. Gukovskii G. R. Ocherki po istorii russkoi literatury i obshchestvennoi mysli XVIII veka (Essays on the History of Russian Literature and Social Thought of the $18^{\text {th }}$ Century). St. Petersburg, Goslitizdat Publ., 1938. 316 p. (in Russian).

19. Iakimovich A. Novoe vremia. Iskusstvo i kul'tura XVII-XVIII vekov (Early Modern Period. Art and Culture of the $17^{\text {th }}-18^{\text {th }}$ Centuries). St. Petersburg, Azbuka-klassika Publ., 2004. 436 p. (in Russian).

20. Jones G. W. Enlightenment, Russian. Craig Ed. (ed.). Routledge Encyclopedia of Philosophy, vol. 3. London; New York, Routledge Publ., 1998. 868 p.

21. Karev A. A. Klassitsizm v russkoi zhivopisi (Classicism in Russian Painting). Moscow, Belyi gorod Publ., 2003. 319 p. (in Russian).

22. Karev A. A. At the Boundaries of $18^{\text {th }}$-Century Russian Portraiture. Zakharova A. V.; Maltseva S. V.; Staniukovich-Denisova E. Iu. (eds.). Actual Problems of Theory and History of Art, vol. 10. Moscow, Lomonosov Moscow State University; Saint-Petersburg, NP-Print Publ., 2020, pp. 220-229.

23. Kochetkova N. D. Literatura russkogo sentimentalizma (Literature of Russian Sentimentalism). St. Petersburg, Nauka Publ., 1994. 279 p. (in Russian).

24. Kolmogorova E. E. The Theme of Family in the Russian Portrait of the Second Half of the $18^{\text {th }}-$ Early $19^{\text {th }}$ Centuries. Culture and Civilization, 2017, vol. 7, is. 1A, pp. 546-555. Available at: http://publishingvak.ru/file/archive-culture-2017-1/55-kolmogorova.pdf (accessed 17 January 2020) (in Russian).

25. Kolmogorova E. E. Family Portraiture in $18^{\text {th }}$ Century Russia and All-European Artistic Heritage. Zakharova A. V.; Maltseva S. V.;Staniukovich-Denisova E. Iu. (eds.). Actual Problems of Theory and History of Art, vol. 6. St. Petersburg, NP-Print Publ., 2016, pp. 534-551 (in Russian).

26. Kon I. S. Druzhba (Friendship). St. Petersburg, Piter Publ., 2005. 329 p. (in Russian).

27. Kornbluth M.L. Friendship in Fashion: The Dramatic Treatment of Friendship in the Restoration and Eighteenth Century. Ph. D. Thesis. Philadelphia, Pennsylvania University, 1956, 236 p. (unpublished). Available at: https://proxy.library.spbu.ru:2345/pqdtglobal/docview/301924276/3B076D36DF3439CP Q/1?accountid=28393 (accessed 2 March 2020).

28. Kovalenskaia N. N. Russkii klassitsizm: zhivopis', skul'ptura, grafika (Russian Classicism: Painting, Sculpture, Drawing). Moscow, Iskusstvo Publ., 1964. 703 p. (in Russian).

29. Lotman Iu. M. Sotvorenie Karamzina (Creation of Karamzin). Moscow, Kniga Publ., 1987. 336 p. (in Russian).

30. McBurney E. Art and Power in the Reign of Catherine the Great: The State Portraits. New York, Columbia University Press Publ., 2014. 426 p.

31. Medakovich M. A. Between Friends: Representations of Female Sociability in French Genre Painting and Portraiture, 1770-1830. Ph. D. Thesis. Chapel Hill, The University of North Carolina, 2012. 346 p. (unpublished). Available at: https://cdr.lib.unc.edu/concern/dissertations/np193b12r (accessed 25 February 2020).

32. Mikhailova K. V.; Smirnov G. V. (eds.). Portretnaia miniatiura iz sobraniia Gosudarstvennogo Russkogo muzeia, XVIII - nachalo XX veka (Portrait Miniatures from the Collection of the Russian Museum, $18^{\text {th }}-$ Early 20 $0^{\text {th }}$ Century). St. Petersburg, Khudozhnik RSFSR Publ., 1979. 316 p. (in Russian).

33. Nikitin S. A. (ed.). Russkie portrety XVIII i XIX vekov. Izdanie velikogo kniazia Nikolaia Mikhailovicha Romanova (Russian Portraits of the $18^{\text {th }}$ and $19^{\text {th }}$ Centuries. Edition of Grand Duke Nikolai Mikhailovich Romanov), vol. 3, 1907. Moscow, Tri veka istorii Publ., 2000. 688 p. (in Russian).

34. Olausson M. (ed.). Catherine the Great \& Gustav III: Exhibition Catalogue, Nationalmuseum, 9.10.199828.02.1999. Stockholm, Nationalmuseum; St. Petersburg, The State Hermitage Museum Publ., 1999. 640 p.

35. Olson R. J. M.; Cavina A. O. Identifying Felice Giani’s Double Portrait with Michael Köck and the Friendship Portrait in Late Settecento Rome. Mitteilungen des Kunsthistorischen Institutes in Florenz, 2013, vol. 55, no. 2, pp. 266-285.

36. Pastushenko L. M. Formation of Friendly Message Genre in Russian Poetry of the Late $18^{\text {th }}$ Century. Vestnik Kamchatskoi regional'noi assotsiatsii "Uchebno-nauchnyi tsentr". Gumanitarnye nauki (Bulletin of the Kamchatka Regional Association "Educational and Scientific Center". Humanities), 2012, no. 2 (20), pp. 78-86 (in Russian). 
37. Petrova E.; Goldovskii G. (eds.). Gosudarstvennyi Russkii muzei. General'nyi katalog muzeinogo sobraniia. Zhivopis': Pervaia polovina XIX veka (The State Russian Museum. General Catalogue of the Museum Collection. Painting: the First Half of the $19^{\text {th }}$ Century), vol. 2. St. Petersburg, Palace Editions Publ., 2002. 232 p. (in Russian).

38. Pevsner L.; Sakharova I. Portretnaia miniatiura XVIII - nachala XX veka (Portrait Miniature of the $18^{\text {th }}-20^{\text {th }}$ Centuries). Moscow, Krasnaia Ploschchad' Publ., 1997. 262 p. (in Russian).

39. Pfeiffer J. Männerfreundschaften in der Literatur des 18. Jahrhunderts. Freiburger Frauen Studien. 2000, no. 1, pp. 193-210 (in German).

40. Podstanitskii S. A. (ed.). Materialy po russkoi ikonografii (Materials on Russian Iconography), no. 2. Moscow, Russkie Vitiazi Foundation Publ., 2013. 192 p. (in Russian).

41. Pott U. (ed.). Das Jahrhundert der Freundschaft: Johann Wilhelm Ludwig Gleim und seine Zeitgenossen (Schriften des Gleimhauses Halberstadt). Göttingen, Wallstein Publ., 2004. 144 p. (in German).

42. Reddy M. W. The Navigation of Feeling: A Framework for the History of Emotions. Cambridge, Cambridge University Press Publ., 2001. 380 p.

43. Renne E. State Hermitage Museum Catalogue. Sixteenth- to Nineteenth-Century British Painting. New Haven; London, Yale University Press Publ., 2011. 416 p.

44. Retford K. The Conversation Piece. Making Modern Art in Eighteenth-Century Britain. New Haven; London, Yale University Press Publ., 2017. 425 p.

45. Schmitter A. M. Representation and the Body of Power in French Academic Painting. Journal of the History of Ideas, 2002, vol. 63, no. 3, July, pp. 399-424.

46. Skvortcova E. A. Allegorical Program of "Portrait of Tsarevny Anna Petrovna and Elizaveta Petrovna" from Plane-Tree Study in the Marly Palace in Peterhof. Chelovek i Kul'tura (Person and Culture), 2019, no. 5, pp. 113-120 (in Russian).

47. Skvortcova E. A. Lost Portraits of Peter I's Children from Plane-Tree Study in the Marly Palace in Peterhof: Mysteries of Iconography. Transactions of the State Hermitage Museum, vol. 101: Personalities from Peter the Great's Time - 2019, pp. 295-310 (in Russian).

48. Skvortcova E. "Portrait of Grand Duke Alexander and Constantine" by R. Brompton (1781): Symbolism and European Counterparts. Vspomogatel'nye istoricheskie distsipliny v sovremennom nauchnom znanii. Materialy XXXIII Mezhdunarodnoi nauchnoi konferentsii (Auxiliary Sciences of History in Contemporary Scientific Knowledge. Proceedings of $23^{\text {rd }}$ International Scientific Conference). Moscow, Institute of World History, Russian Academy of Sciences Publ., 2020, pp. 372-374 (in Russian).

49. Smith D. R. Rembrandt's Early Double Portraits and the Dutch Conversation Piece. The Art Bulletin, 1982, vol. 64, no. 2, pp. 259-288.

50. Tyukhmeneva E.A. Iskusstvo triumfalnykh vrat $v$ Rossii pervoi poloviny XVIII veka. Problemy panegericheskgo napravleniia (The Art of Triumphal Arches in Russia in the First Half of the $18^{\text {th }}$ Century. Problems of Panegiric Trend). Moscow, Progress-Traditsiia Publ., 2005. 328 p. (in Russian).

51. Vasser L. Europäische Hofkünstler in St. Petersburg in der Ersten Hälfte des 18. Jahrhunderts: Bildhauer Bartolomeo Carlo Rastrelli, Maler Johann Gottfried Tannauer und Louis Caravaque: Ein Beitrag zur "Europäisierung" Russlands. Berlin, Logos Publ., 2015. 343 p. (in German).

52. Vdovin G. V. Persona - Individual'nost' - Lichnost' (Person - Individuality - Personality). Moscow, Progress-Traditsiia Publ., 2005. 248 p. (in Russian).

53. Vlasov V. G. Novyi entsiklopedicheskii slovar' izobrazitel'nogo iskusstva (New Encyclopedic Dictionary of the Fine Arts), vol. 6. St. Petersburg, Azbuka-Klassika Publ., 2007. 591 p. (in Russian).

54. Vlasov V. G. Novyi entsiklopedicheskii slovar' izobrazitel'nogo iskusstva (New Encyclopedic Dictionary of the Fine Arts), vol. 8. St. Petersburg, Azbuka-Klassika Publ., 2008. 844 p. (in Russian).

55. Williams H. Académie Royale. A History in Portraits. Farnham, Ashgate Publ., 2015. 358 p.

56. Zhidkov G. V. Russkoe iskusstvo XVIII veka: Arkhitektura. Skul'ptura. Zhivopis' (18 $8^{\text {th }}$-Century Russian Art: Architecture. Sculpture. Painting). Moscow, Iskusstvo Publ., 1951. 143 p. (in Russian).

57. Zhivov V. M. State Myth in the Epoch of Enlightenment and Its Destruction in Russia in the End of the $18^{\text {th }}$ Century. Danilova I. (ed.). Vek Prosveshcheniia. Rossiia i Frantsiia: Materialy nauchnoi konferentsii "Vipperovskie chteniia - 1987" (The Century of Enlightenment. Russia and France: Proceedings of Conference in Honor of B. R. Vipper - 1987), vol. 20. Moscow, [s.n.], 1989. 300 p. (in Russian).

Title. Sense and Sensibility: The Theme of Friendship in the Russian Portrait Painting of the Enlightenment Era

Authors. Chebakova, Polina Aleksandrovna - M. A., postgraduate student. Saint-Petersburg State University, Universitetskaia nab., 7/9, 199034 St. Petersburg, Russian Federation. st050356@student.spbu.ru 
Skvortcova, Ekaterina Aleksandrovna - Ph. D., associate professor. Saint-Petersburg State University, Universitetskaia nab., 7/9, 199034 St. Petersburg, Russian Federation. e.skvortsova@spbu.ru

Abstract. In the policed society of the $18^{\text {th }}$ century, the phenomenon of friendship, as M. W. Reddy asserts, evolved into a new form of sociability which offered an emotional refuge from the code of honor and became central for the culture of the Enlightenment. Although there was no necessary contradiction between reason and emotion, sense and sensibility were understood as opposite poles and the concept of friendship was oscillating between them. The present paper reveals the peculiar features of perception of friendship in the second half of the $18^{\text {th }}$ century in Russia when its importance for culture rapidly increased on the material of double portrait painting. The specifics of the Russian Enlightenment defined by V. Zhivov as "primarily mythological performance of the state power" were expressed in the idea of the state. This was reflected in male double portrait painting developing the traditions of parallel depiction and the iconography of gestures which first emerged in the Russian art of the first half of the $18^{\text {th }}$ century in allegorical compositions celebrating peace treaties. In contrast, the European understanding of male friendship visualized in portrait painting was broader, embracing emotional aspects as well (creative friendship, admiration of art). While male friendship in Russia was understood as a political union or collaboration, the notion of sensibility, i.e. friendship as union of hearts, was usually associated with the female portrait. Models for female friends portraits were always unmarried young ladies: the family life was perceived as dominated exclusively by the responsibilities of a caring wife and mother. Overall, both the female and male friends portrait painting in Russian art, in contrast with European, appears to be inseparable from the family portrait painting in its reduced variant, i.e. portraits of brothers or sisters. The few exceptions are connected with the corporate friendship of young people inside closed educational institutions established by the will of Catherine II in order to breed "an ideal man and a perfect citizen".

Keywords: friendship, friendship portrait, Enlightenment, sense and sensibility, Russian portrait, $18^{\text {th }}$ century art, family portrait

Название статьи. Разум и чувство: тема дружбы в русском портрете эпохи Просвещения

Сведения об авторах. Чебакова Полина Александровна - студент магистратуры. Санкт-Петербургский государственный университет, Университетская наб., д. 7/9, Санкт-Петербург, Российская Федерация, 199034. st050356@student.spbu.ru

Скворцова Екатерина Александровна - кандидат искусствоведения, доцент. Санкт-Петербургский государственный университет, Университетская наб., д. 7/9, Санкт-Петербург, Российская Федерация, 199034.e.skvortsova@spbu.ru

Аннотация. В обществе XVIII в., где все стороны жизни подлежали контролю со стороны государства, дружба, как доказал М. В. Редди, становится одной из новых форм проявления общительности, предоставлявших «эмоциональное убежище», и приобретает центральное значение для культуры. Хотя в эпоху Просвещения, как показали исследования последних лет, понятия разума и чувства не были взаимоисключающими, они всё же воспринимались как два полюса, определяющие в том числе специфику концепции дружбы. В статье рассмотрены особенности визуализации представлений о дружбе в России второй половины XVIII в., когда её значение для культуры стремительно возросло, на материале двойного портрета. Своеобразие русского Просвещения, определённое В. М. Живовым как «преимущественно мифологическое действо государственной власти», предопределило государственный акцент в мужских двойных портретах, развивающих традиции параллельного изображения и иконографии, в первой половине XVIII в. в России воплощавшиеся в аллегорических композициях в честь заключения мира. Мужская дружба в России понималась прежде всего в категориях разума, как политический союз или соратничество; мужской дружеский портрет лишён ноток чувствительности, которые находят отражение в некоторых разновидностях европейского двойного мужского портрета типа "conversation piece". Дружба, трактованная в категориях чувства как союз сердец, в России была сопряжена исключительно с женским портретом. В качестве моделей женских дружеских портретов почти всегда выступают незамужние девушки: жизнь в браке, всецело подчинённая обязанностям супруги и матери, не оставляла женщине пространства для иных форм общения. В целом как женский, так и мужской дружеский портрет в России второй половины XVIII в. в отличие от Европы был неразрывно связан с семейным (портрет братьев или сестёр). Редкие исключения связаны с корпоративной дружбой в рамках закрытых учебных заведений, учреждённых волей Екатерины для воспитания совершенных людей и идеальных граждан.

Ключевые слова: дружба, дружеский портрет, эпоха Просвещения, разум и чувство, русский портрет, искусство XVIII века, семейный портрет 


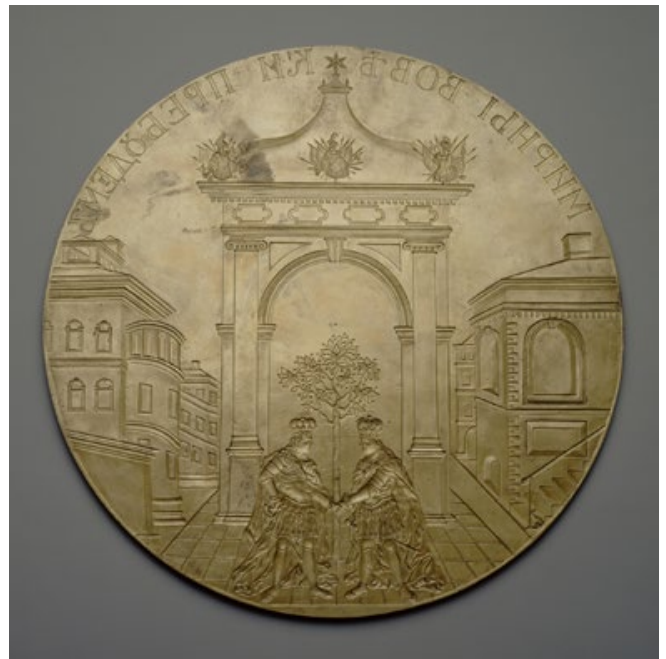

III. 22. Rastrelli B. C., Nartov A. Medallion (model for a die) with a Depiction of the Allegory of the Nystadt Peace (30 August 1721). 1720s. Bronze. 35,5 cm. @ State Hermitage, Saint-Petersburg, 2020

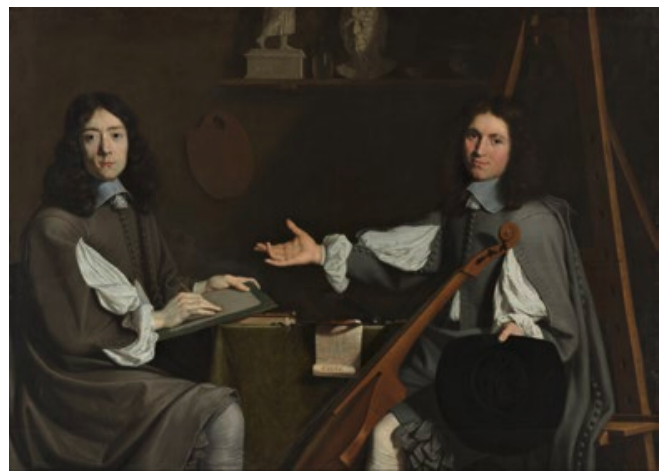

III. 24. Champaigne, J.-B. de, Plattemontagne, N. de. Double Self-Portrait of Jean-Baptiste de Champaigne et Nicolas de Plattemontagne. 1654. Oil on canvas. $132 \times 185 \mathrm{~cm}$. Museum Boijmans Van Beuningen, Rotterdam / Creditline photographer: Studio Tromp

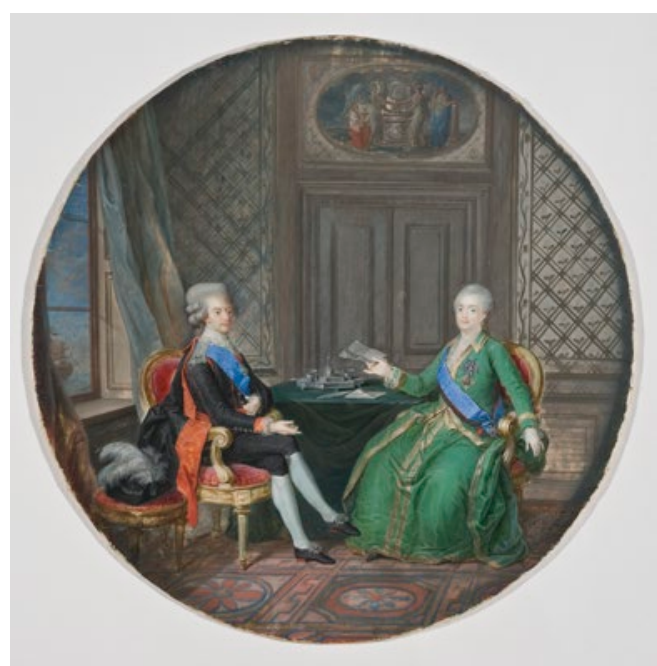

III. 23. Høyer C. King Gustavus III of Sweden and Catherine II of Russia in Fredrikshamn 1783. 1784. Watercolour on parchment. $26 \mathrm{~cm}$ (diameter). Nationalmuseum, Stockholm. Photo: Erik Cornelius/ Nationalmuseum

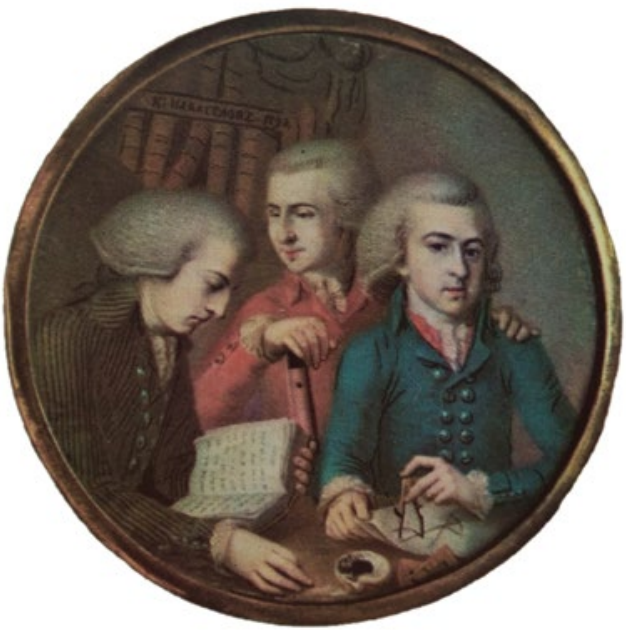

III. 25. Novoselov K. Portrait of Three Pupils of the Academy of Fine Arts (?). 1792. Watercolour, gouache on ivory. $7 \mathrm{~cm}$ (diameter). State Russian museum, Saint-Petersburg 


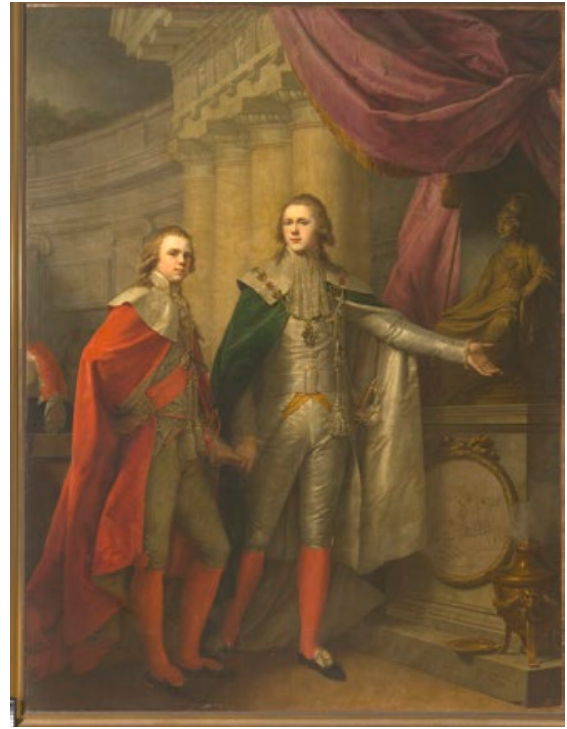

III. 26. Lampi the Elder J. B. Portrait of Grand Duke Alexander and Grand Duke Constantine. 1795. Oil on canvas. $250 \times 200 \mathrm{~cm}$. @ State Hermitage, Saint-Petersburg, 2020

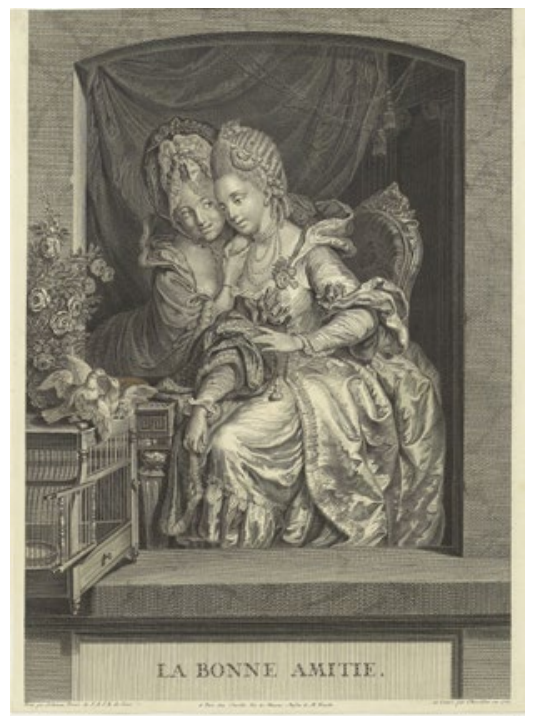

III. 28. Chevilett J. after Schenau J. E. "La bonne Amitié, ou le mistère éclairci". 1769. Etching, paper. $44,5 \times 32,5 \mathrm{~cm}$. Deutsches Damast- und Frottiermuseum Großschönau, inv. no. DDFM 1956-1025.

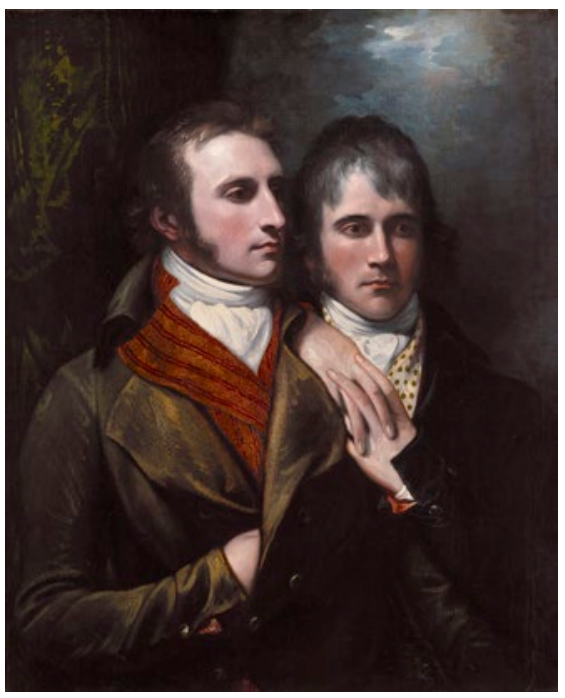

III. 27. West B. Raphael West and Benjamin West Jr., Sons of the Artist. C. 1796. Oil on canvas. $92.1 \times 74.4 \mathrm{~cm}$. The Nelson-Atkins Museum of Art, Kansas City, Missouri. Gift of the Laura Nelson Kirkwood Residuary Trust, 44-41/1. Image courtesy of The Nelson-Atkins Museum of Art, Media Services / Photo: Jamison Miller

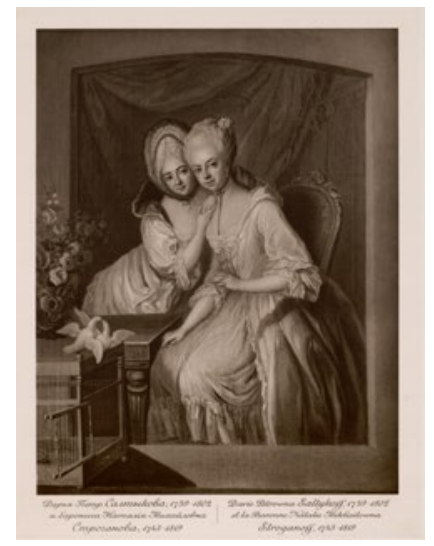

III. 29. Portrait of Cousins Countess Daria Petrovna Saltykova and Baroness Nataliia Mikhailovna Stroganova. Reproduction of a Portrait by Unknown Artist from "Edition of Grand Duke Nikolai Mikhailovich. Russian Portraits of the $18^{\text {th }}$ and $19^{\text {th }}$ Centuries" (vol. 5, no. 2. Saint-Petersburg, 1905). Phototype of Ekspeditsiia zagotovleniia gosudarstvennykh bumag. 22,8×17,7 $\mathrm{cm}$. State museum of L. N. Tolstoy, Moscow, inv. ГMT K-703/7 КП 5777/455 